\title{
The Effects of Ni on Tensile Properties of Al-6Si-0.5Mg Cast Alloys During Precipitation Hardening
}

\author{
A. Hossain", A. S. W. Kurny \\ Bangladesh University of Engineering and Technology, Department of Materials and Metallurgical Engineering, Dhaka 1000, Bangladesh \\ *Corresponding Author: ah_buetmmesgfl@live.com
}

Copyright $@ 2014$ Horizon Research Publishing All rights reserved.

\begin{abstract}
The microstructure, tensile properties and fracture behavior of the Al-6Si-0.5Mg and Al-6Si-0.5Mg-2Ni cast alloys were investigated and the results showed that the $\mathrm{Mg}_{2} \mathrm{Si}, \mathrm{Al}_{3} \mathrm{Ni}$ and $\mathrm{Si}$ hard particles produced by precipitation hardening have great effects. The homogenized $\left(24 \mathrm{hr}\right.$ at $\left.500^{\circ} \mathrm{C}\right)$ and solutionized $\left(2 \mathrm{hr}\right.$ at $\left.540^{\circ} \mathrm{C}\right)$ cast alloys were subjected to ageing treatment from room temperature to $300^{\circ} \mathrm{C}$. The yield strength and fracture strength of the alloys increased with the ageing temperature and maximum at peakaged condition $\left(1 \mathrm{hr}\right.$ at $\left.225^{\circ} \mathrm{C}\right)$ where as ductility and impact toughness decreased with ageing temperature reaching the minimum at the peakaged condition. The properties of $\mathrm{Ni}$ content and $\mathrm{Ni}$ free Al-6Si-0.5Mg alloys were found to exhibit marked differences depending on the intermetallic phases and the heat treatment conditions. SEM-analysis revealed the existence of $\mathrm{Al}_{3} \mathrm{Ni}$-phases and the microstructure of broken tensile specimens show both the particle fracture and interface de-bonding affect the fracture behavior of the alloys.
\end{abstract}

Keywords Tensile properties, $\mathrm{Al}_{3} \mathrm{Ni}$ particle, Precipitation hardening, Fracture behavior, SEM

\section{Introduction}

Al-Si based multi-component foundry alloys provide several advantageous characteristics such as good castability, high corrosion and wear resistance as well as high thermal conductivity and adequate strength at elevated temperatures [1]. Al-Mg-Si alloys have been widely used in transportation systems owing to their fair strength, weldability and corrosion resistance. The precipitation sequence of solution-treated Al-Mg-Si ternary alloys during artificial aging can be reported to be: $\alpha$ supersaturated solid solution (SSS) $\rightarrow$ GP-I zones $\rightarrow$ metastable needle-like $\beta^{\prime \prime}$ precipitates (or called GP-II zones; formed through the transformation of GP-I as nuclei) $\rightarrow$ metastable rod-like (or lath-like) $\beta^{\prime}$ precipitates $\rightarrow$ stable $\beta$ phase [2].

When a heat-treatable A356 aluminum alloy undergoes precipitation hardening (age-hardening), fine precipitants will dissolve completely in saturated matrix to achieve high strength in material [3]. The supersaturated solid solution undergoes aging treatment; a large amount of small and uniformly distributed precipitants will appear thus the mechanical properties of the material can be improved. Uniform and delicate $\mathrm{Mg}_{2} \mathrm{Si}$ precipitants can be obtained in the matrix of a heat-treatable Al-Si-Mg casting part with T6 treatment (which involves solution treatment, quenching and artificial aging), leading to improvements in its tensile strength, elongation and toughness $[4,5]$.

Additions of $\mathrm{Ni}$ lead to the formation of $\mathrm{Al}_{3} \mathrm{Ni}$ in the aluminum matrix through eutectic reaction during solidification. In previous work $\mathrm{Ni}$ was identified to significantly enhance the high-temperature performance of Al-Si foundry alloys, though just to a certain level, depending on the fraction of eutectic phase in the alloy. $\mathrm{Ni}$ stabilizes the contiguity of the eutectic network by increasing the volume fraction of rigid phases $\left(\mathrm{Si}+\mathrm{Al}_{3} \mathrm{Ni}\right)$ in the eutectic [6-9]. Heat treatment (HT) is a commonly used technique to enhance the mechanical properties of the respective alloys, such as strength (HT: T6) or ductility (HT: $\mathrm{T} 4, \mathrm{~T} 7)$. However, during a solution treatment the eutectic $\mathrm{Si}$ spheroidizes and its aspect ratio decreases, which results in a loss of the contiguity of the eutectic platelets $[6,10]$.

The objective of this research work was to study the effects of $\mathrm{Ni}$ on tensile properties of $\mathrm{Al}-6 \mathrm{Si}-0.5 \mathrm{Mg}$ cast alloy under various ageing conditions.

\section{Materials and Methods}

The $\mathrm{Ni}$ free Al-6Si-0.5Mg and $\mathrm{Ni}$ added Al-6Si-0.5Mg-2Ni alloys were used in this study. The alloys were prepared in a natural gas heating clay-graphite crucible furnace. In the process of preparation of the alloys the commercially Al-Si binary alloy and pure aluminium $(99.7 \%$ purity) were taken as the starting material. The Ni chips were charged into the bottom of furnace. Then the aluminium and aluminium-silicon binary alloy melted into the clay-graphite crucible, and then magnesium ribbon (99.7\% purity) was added into solution. The final temperature of the melt was 
always maintained at $910 \pm 15^{\circ} \mathrm{C}$ with the help of the electronic controller. The melt was degassing with solid hexachloroethane $\left(\mathrm{C}_{2} \mathrm{Cl}_{6}\right)$ and homogenized by stirring at $690^{\circ} \mathrm{C}$ before casting. Casting was done in metal moulds preheated to $200^{\circ} \mathrm{C}$. Mould sizes were $15 \mathrm{~mm}$ x $150 \mathrm{~mm}$ x $300 \mathrm{~mm}$. All the alloys were analysed by wet chemical and spectrochemical methods simultaneously. The compositions of the samples are shown in Table 1.

The cast samples were first ground properly to remove the oxide layer from the surface. All the alloys were homogenized at $500^{\circ} \mathrm{C}$ for 24 hours. The tensile and impact specimens were prepared from the homogenized alloys according to ASTM standard of aluminum alloys. The homogenized samples were solution treated at $540^{\circ} \mathrm{C}$ for 2 hours and quenched into salt iced water solution. The solutionized samples were aged isochronally for 1 hour at different temperatures up to $300^{\circ} \mathrm{C}$. Tensile testing was carried out in an Instron testing machine at strain rates of $10^{-3} / \mathrm{s}$. The averages of three consistent test results were accepted as the tensile test values for the corresponding sample. The Charpy impact test sample has $10 \mathrm{~mm} \times 10 \mathrm{~mm} x$ $55 \mathrm{~mm}$ dimensions, a $45^{\circ} \mathrm{V}$ notch of $2 \mathrm{~mm}$ depth and a 0.25 $\mathrm{mm}$ root radius was hit by a pendulum at the opposite end of the notch. The pendulum was set at a certain height was released and stuck the specimen at the opposite end of the notch to produce a fractured sample. The absorbed energy required to produce two fresh fracture surfaces were recorded in the unit of Joule. Scanning Electron Microscopy (SEM) with Energy Dispersive Spectroscopy (EDS) of selected sample was observed in a Scanning Electron Microscope.

\section{Results and Discussion}

\subsection{Effects of Ni on Yield strength}

Fig.1 illustrates the effect of $\mathrm{Ni}$ on the yield strength $(0.2 \%$ proof strength) of $\mathrm{Al}-6 \mathrm{Si}-0.5 \mathrm{Mg}$ cast alloy at various ageing temperatures. The graph indicates that the yield strength of $\mathrm{Ni}$ containing alloy (Al-6Si-0.5Mg-2Ni) higher than $\mathrm{Ni}$ free alloy $(\mathrm{Al}-6 \mathrm{Si}-0.5 \mathrm{Mg}$ ) all over the ageing conditions except aged at $200^{\circ} \mathrm{C}$. With increase of ageing temperature, more intermetallic reinforcement particles are in stable form. The Al-6Si-0.5Mg-2Ni alloy shows $47.73 \%$ higher yield strength than the $\mathrm{Al}-6 \mathrm{Si}-0.5 \mathrm{Mg}$ alloy over the solution treated condition. At peak aged condition $\left(1 \mathrm{hr}\right.$ at $\left.225^{\circ} \mathrm{C}\right)$ Al-6Si-0.5Mg-2Ni alloy shows $27.35 \%$ higher yield strength than $\mathrm{Al}-6 \mathrm{Si}-0.5 \mathrm{Mg}$ alloy and $14.62 \%$ over the solutionized condition. The intermetallic particles could contribute as a reinforcement effect in the Al-alloy matrix. The higher yield strength is due to the effect of precipitation hardening.

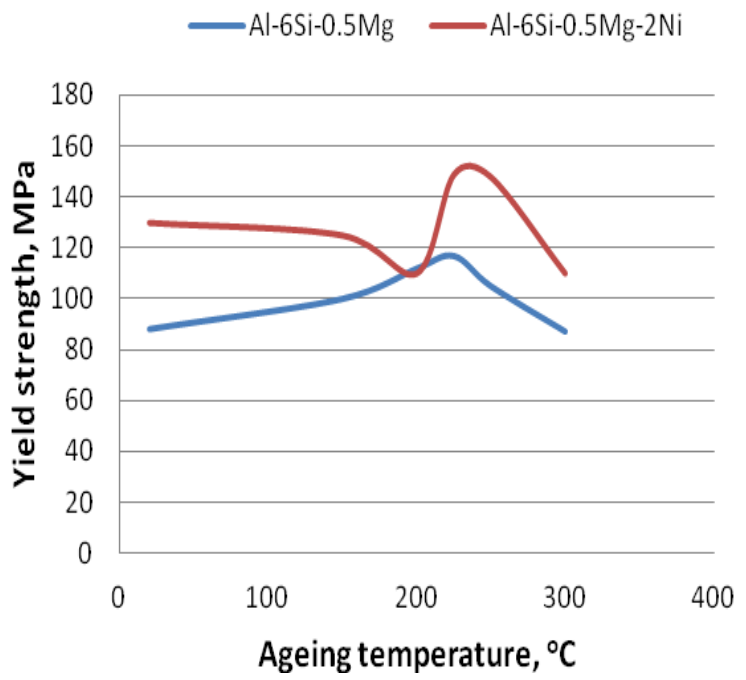

Figure 1. Effects of Ni addition on the yield strength of Al-6Si-0.5Mg cast alloys at various ageing conditions

\subsection{Effects of Ni on Fracture strength}

The ultimate tensile strength (Fig.2) follows the same trend as the yield strength of Al-6Si-0.5Mg and Al-6Si-0.5Mg-2Ni alloys. There is an increase of $34.55 \%$ fracture strength of $\mathrm{Ni}$ containing $\mathrm{Al}-6 \mathrm{Si}-0.5 \mathrm{Mg}-2 \mathrm{Ni}$ alloy than the $\mathrm{Al}-6 \mathrm{Si}-0.5 \mathrm{Mg}$ alloy over the solution treated condition. At peak aged condition $\left(1 \mathrm{hr}\right.$ at $\left.225^{\circ} \mathrm{C}\right)$ Al-6Si- $0.5 \mathrm{Mg}-2 \mathrm{Ni}$ metal alloy is $20.95 \%$ higher fracture strength over the solution treated condition and $25.17 \%$ higher over the peakaged $\mathrm{Al}-6 \mathrm{Si}-0.5 \mathrm{Mg}$ alloy. Further ageing $\left(250^{\circ} \mathrm{C}\right.$ and $\left.300^{\circ} \mathrm{C}\right)$ beyond the peakaged condition, the fracture strength and yield strength for both the alloys decrease due to overage.

Table1. Chemical composition of the experimental alloys (wt \%)

\begin{tabular}{|c|c|c|c|c|c|c|c|c|}
\hline Alloy & $\% \mathrm{Si}$ & $\% \mathrm{Mg}$ & $\% \mathrm{Cu}$ & $\% \mathrm{Ni}$ & $\% \mathrm{Fe}$ & $\% \mathrm{Mn}$ & $\% \mathrm{Ti}$ & $\% \mathrm{Al}$ \\
\hline $\mathrm{Al}-6 \mathrm{Si}-0.5 \mathrm{Mg}$ & 5.802 & 0.441 & 0.006 & 0.006 & 0.146 & 0.002 & 0.099 & $\mathrm{Bal}$ \\
\hline $\mathrm{Al}-6 \mathrm{Si}-0.5 \mathrm{Mg}-2 \mathrm{Ni}$ & 5.935 & 0.440 & 0.007 & 2.220 & 0.141 & 0.003 & 0.088 & Bal \\
\hline
\end{tabular}




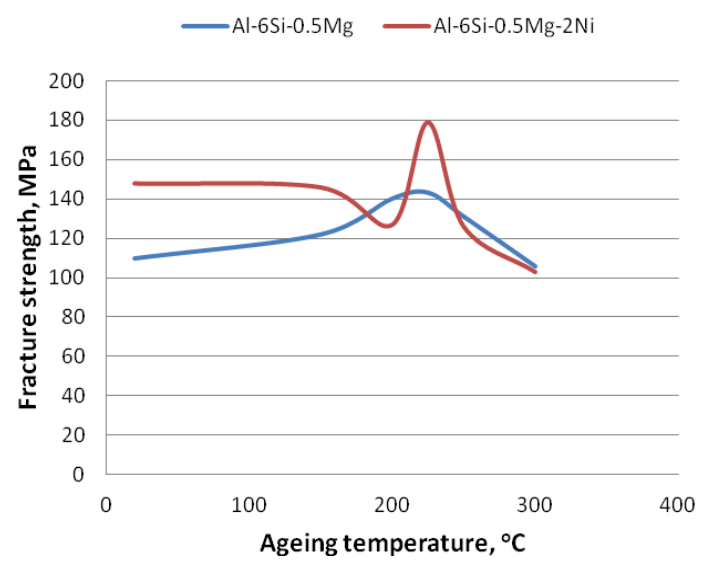

Figure 2. Effects of $\mathrm{Ni}$ addition on the fracture strength of $\mathrm{Al}-6 \mathrm{Si}-0.5 \mathrm{Mg}$ cast alloys at various ageing conditions.

\subsection{Effects of Ni on ductility (\% elongation)}

The effect of Ni addition on ductility (\% elongation) of $\mathrm{Al}-6 \mathrm{Si}-0.5 \mathrm{Mg}$ alloy at various ageing temperatures is shown in fig.3.The $\mathrm{Ni}$ containing $\mathrm{Al}-6 \mathrm{Si}-0.5 \mathrm{Mg}-2 \mathrm{Ni}$ alloy shows lower ductility than the $\mathrm{Ni}$ free $\mathrm{Al}-6 \mathrm{Si}-0.5 \mathrm{Mg}$ alloy at all ageing conditions. The $\%$ elongation of $\mathrm{Al}-6 \mathrm{Si}-0.5 \mathrm{Mg}-2 \mathrm{Ni}$ alloy is $30.77 \%$ lower than the $\mathrm{Al}-6 \mathrm{Si}-0.5 \mathrm{Mg}$ alloy at the peakaged condition. Beyond the $225^{\circ} \mathrm{C}$ the ductility increases with ageing temperature for both alloys.

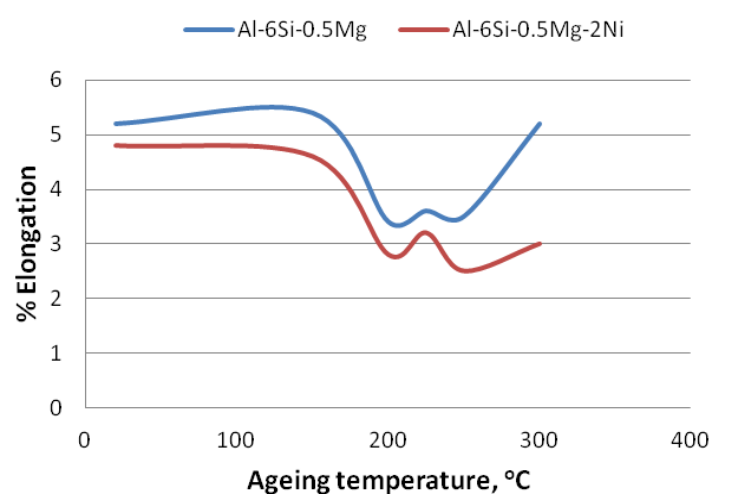

Figure 3. Effects of $\mathrm{Ni}$ addition on the ductility (\% elongation) of $\mathrm{Al}-6 \mathrm{Si}-0.5 \mathrm{Mg}$ cast alloys at various ageing conditions.

\subsection{Effects of Ni on Impact toughness}

Fig. 4 shows the $\mathrm{Ni}$ free and $\mathrm{Ni}$ content $\mathrm{Al}-6 \mathrm{Si}-0.5 \mathrm{Mg}$ alloys absorbed energy as a function of the artificial ageing temperature. At solution treated condition, the Ni containing Al- $6 \mathrm{Si}-0.5 \mathrm{Mg}-2 \mathrm{Ni}$ alloy has shown lower toughness than the $\mathrm{Ni}$ free Al-6Si- $0.5 \mathrm{Mg}$ alloy at all ageing conditions. The toughness of the Al- $6 \mathrm{Si}-0.5 \mathrm{Mg}-2 \mathrm{Ni}$ alloy has reduced maximum at peakaged condition and minimum at solution treated condition. With the ageing temperature increases from room temperature to $225^{\circ} \mathrm{C}$, the absorbed energy decreases for the alloys. The absorbed energy decreased a maximum due to the precipitation of intermetallic phases at peakaged condition. Further ageing $\left(225 \& 300^{\circ} \mathrm{C}\right)$ the absorbed energy increases due to overage.

\subsection{Tensile and impact Fracture Surfaces Analysis}

Fig. 5, 6 and 7 shows the fracture surface of Al-6Si-0.5Mg and $\mathrm{Al}-6 \mathrm{Si}-0.5 \mathrm{Mg}-2 \mathrm{Ni}$ alloys at peakaged condition. The fracture surfaces appear to be rough and normal to the axis of loading. On a microscopic scale, the fracture surfaces appear to contain many microvoids in the matrix. The void coalescence occurs when the voids elongate to the initial inter void spacing. This leads to the dimpled appearance on the fracture surfaces. The dimples are neither uniform nor circular in shape. The matrix-intermetallic particles decohesion is also observed for these alloys. The fracture mechanism is ductile, involving the nucleation, growth, and coalescence of voids in the matrix around the intermetallic particles. The voids grow under both the applied load and the influence of local plastic constrain until a coalescence mechanism is activated, and this followed by the total failure of the alloys.

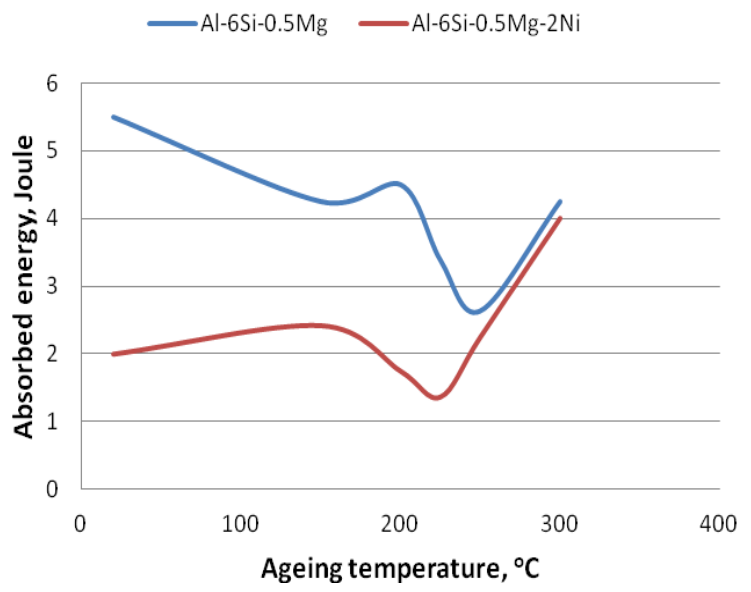

Figure 4. Effects of $\mathrm{Ni}$ addition on the impact absorbed energy of Al-6Si-0.5Mg cast alloys at various ageing conditions

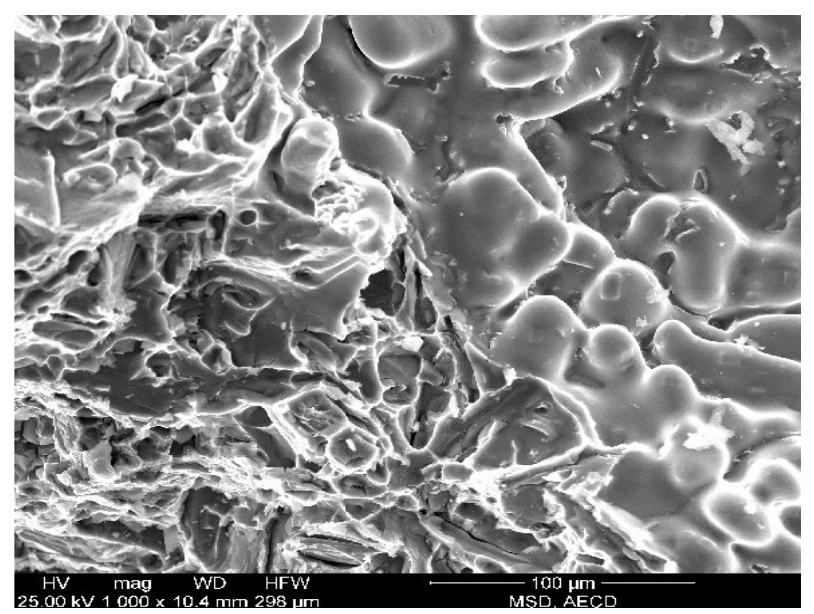

Figure 5. SEM tensile fracture surface of Al-6Si-0.5Mg alloy at peak aged condition. 


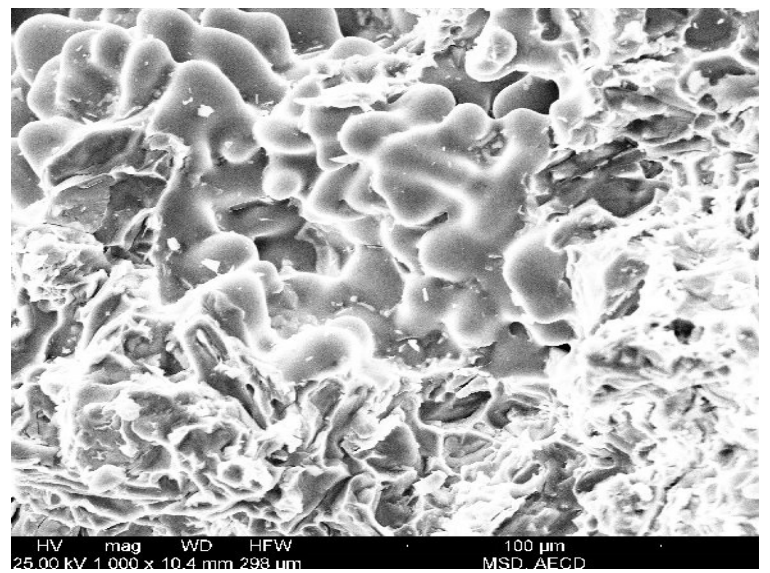

Figure 6. SEM tensile fracture surface of $\mathrm{Al}-6 \mathrm{Si}-0.5 \mathrm{Mg}-2 \mathrm{Ni}$ alloy at peak aged condition.

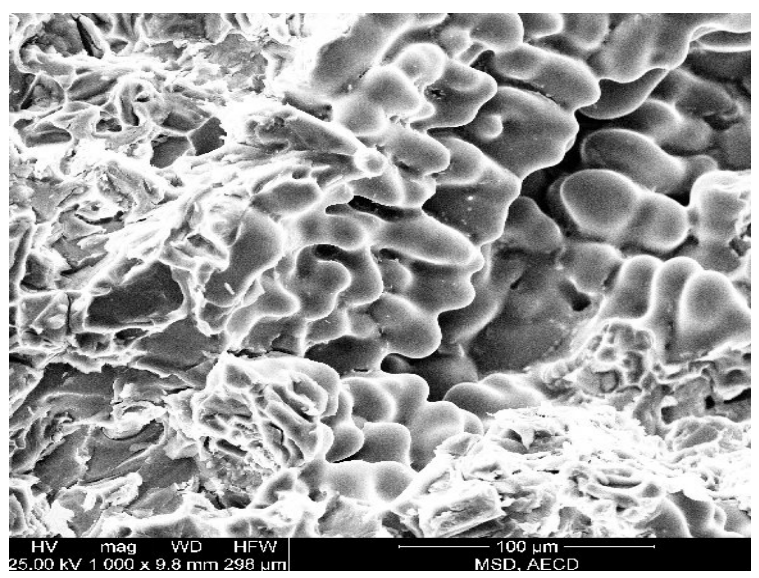

Figure 7. Fracture surface of impact $\mathrm{Al}-6 \mathrm{Si}-0.5 \mathrm{Mg}-2 \mathrm{Ni}$ alloy at peak aged condition $\left(1 \mathrm{hr}\right.$ at $\left.225^{\circ} \mathrm{C}\right)$

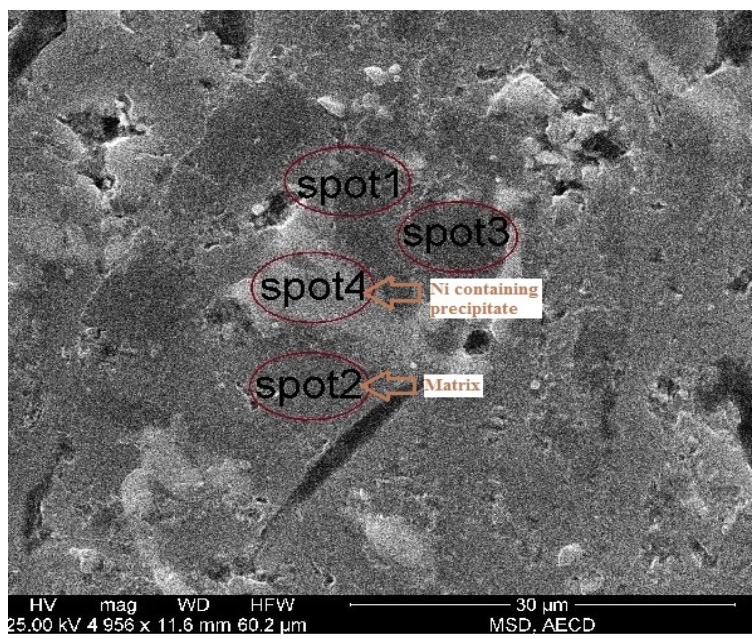

a. SEM image of Al-6Si- $0.5 \mathrm{Mg}-2 \mathrm{Ni}$ cast alloy.

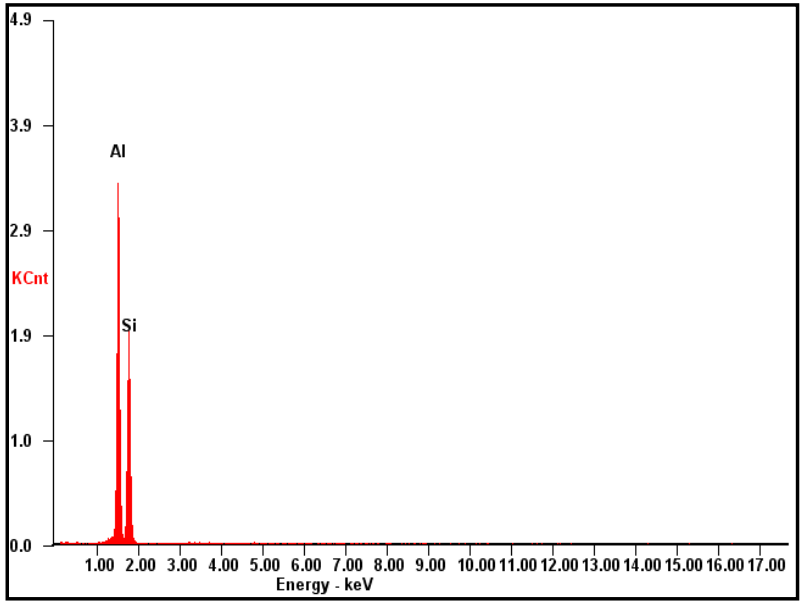

b. EDS analysis of spot1

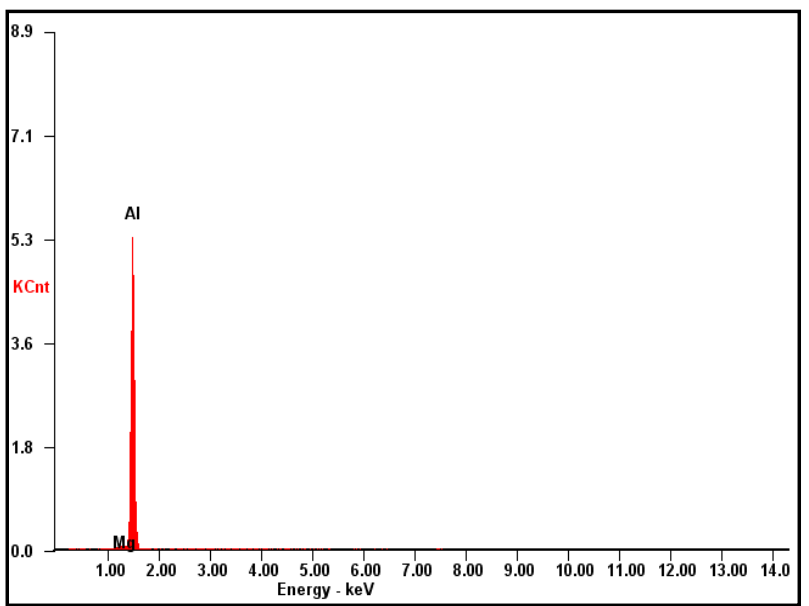

c. EDS analysis of spot2

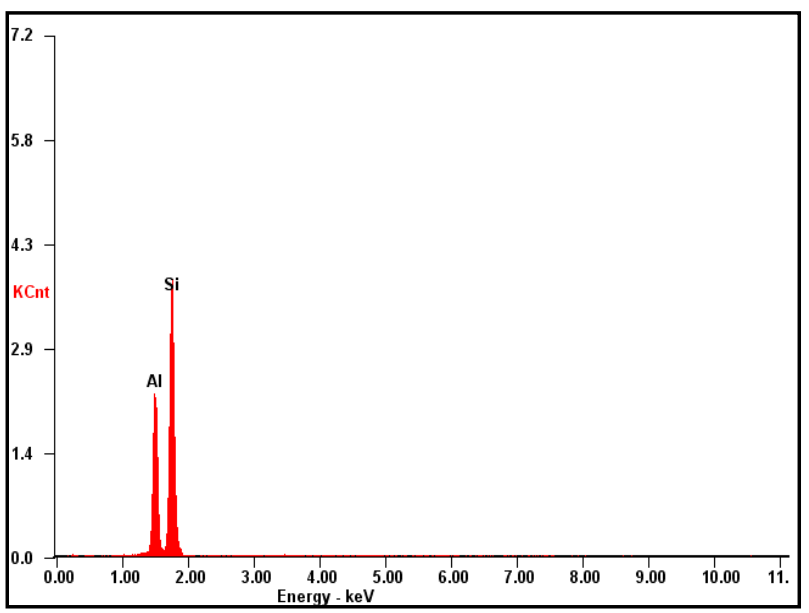

d. EDS analysis 0 f spot3 


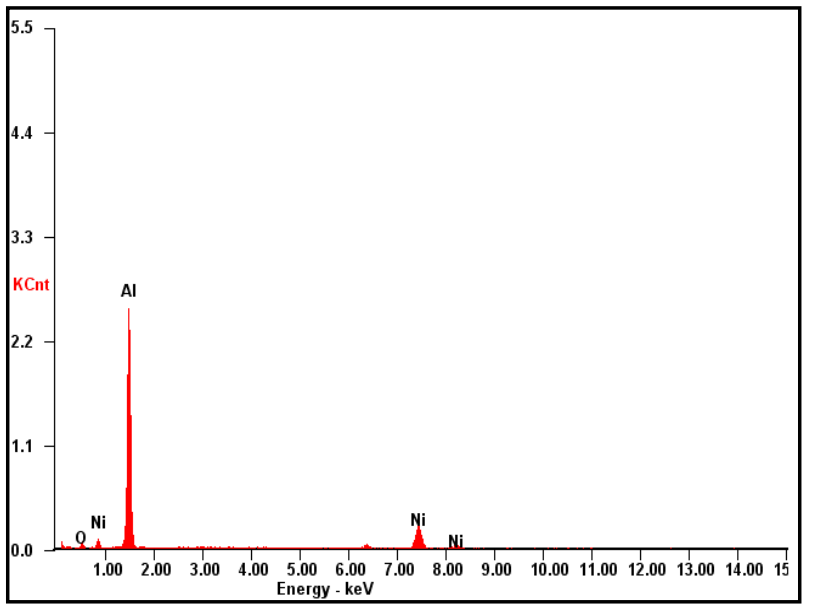

e. EDS analysis of spot4

Figure 8. SEM image (a) and EDS spot analysis (b, c, d \& e) of Al-6Si-0.5Mg-2Ni alloy at peakaged condition.

\subsection{SEM with EDS Spot Analysis}

The Fig.8 illustrating the scanning electron image with EDS spot analysis of the peakaged Al-6Si-0.5Mg-2Ni alloy. $\mathrm{Al}$ is present both in solid solution with the matrix and precipitates. $\mathrm{Mg}$ and $\mathrm{Si}$ combine to form a compound of $\mathrm{Mg}_{2} \mathrm{Si}$, which in turn forms a simple eutectic system. The microstructure of peakaged Al-6Si-0.5Mg- $2 \mathrm{Ni}$ composite reveals particles of intermetallic and precipitated during the heat treatment. The EDS analysis (spot4) indicates the presence of $\mathrm{Ni}$ containing compound $\mathrm{Al}_{3} \mathrm{Ni}$.

\section{Conclusions}

Addition of 2 wt.\% $\mathrm{Ni}$ to the Al-6Si-0.5Mg cast alloy resulted in improved strength and reduced ductility. The yield and fracture strength of $\mathrm{Ni}$ containing Al-6Si-0.5Mg-2Ni alloy were higher than the $\mathrm{Ni}$ free Al-6Si-0.5Mg alloy over the solution treated and peakaged condition. At peakaged condition, $2 \mathrm{wt}$. \% $\mathrm{Ni}$ addition to Al-6Si-0.5Mg improved the strength maximum but reduced the ductility and impact toughness significantly. The SEM with EDS spot analysis reports confirm the presence of $\mathrm{Al}$, $\mathrm{Ni}, \mathrm{Si}$ and $\mathrm{Mg}$ containing precipitates in the Al-6Si-0.5Mg-2Ni alloy.

\section{REFERENCES}

[1] F. Stadler, H. Antrekowitsch, W. Fragner, H. Kaufmann, J. Peter, Uggowitzer, Metals 2012, Edited by Carlos E. Suarez, TMS, 2012.

[2] C. S. Tsao, C. Y. Chen, U. S. Jeng and T. Y. Kuo, Acta Mater., Vol.54, 4621, 2006.

[3] D. Apelian, S. Shivkumar, and G. Sigworth. American Foundry Society Transaction, Vol.97, 727-742, 1989.

[4] S. Shivkumar, C. Keller and D. Apelian. American Foundry Society Transaction, Vol.98, 905-911, 1990.

[5] R. Sinfield, and D. A. Harris. Journal of Australian Institute of Metals, Vol.20, No.1, 44-47, 1975.

[6] Z. Asghar et al., Mater. Sci. and Eng. A, Vol.527, 5691-5698, 2010.

[7] F. Stadler et al., Mater. Sci. Forum, Vol.690, 274-277, 2011.

[8] F. Stadler et al., Giesserei, Vol.98, 26-31, 2011.

[9] F. Lasagni et al., Acta Mater., Vol.55, 3875 -3882, 2007.

[10] I. Sayavur Bakhtiyarov, Magnesium Technology 2003 Edited by Howard I. Kaplan TMS (The Minerals, Metals \& Materials Society), 2003. 